

\title{
PENGARUH PENAMBAHAN BAHAN ADITIF ANTI STRIPPING TERHADAP KINERJA CAMPURAN ASPAL
}

\author{
Refanti Angelia Simanjuntak ${ }^{1}$, Iphan Fitrian Radam ${ }^{2 *}$ \\ 1) Universitas Lambung Mangkurat (email: refantiangelia.s@gmail.com) \\ 2) Program Studi Magister Teknik Sipil Universitas Lambung Mangkurat (email: \\ ifradam@ulm.ac.id)
}

\section{Info Artikel \\ Riwayat Artikel: \\ Dikirim :21-12-21 \\ Direvisi :27-12-21 \\ Diterima :31-12-21}

Kata Kunci:

$A C$-WC, Anti Stripping

Agent, Kadar Optimum,

Spesifikasi Bina Marga,

T-MEN L300A.

\begin{abstract}
ABSTRAK
Anti Stripping Agent adalah aditif yang dapat merubah sifat aspal dan agregat serta meningkatkan daya lekat sehingga memperpanjang umur rencana, mengurangi efek negatif dari air dan kelembaban. Hal ini akan mengurangi terjadinya pelepasan butiran pada aspal. Penelitian dilakukan di laboratorium. Dibuat benda uji untuk pengujian Marshall. Tujian penelitian adalah mengetahui nilai optimum penggunaan Anti Stripping Agent jenis T-MEN L300A dengan kadar 0\%, 0,3\%, 0,5\%, 0,7\%, 0,9\%, dan 2\%. Hasil penelitian dengan Anti Stripping Agent didapat nilai optimum sebesar $0,45 \%$. Berdasarkan analisis didapat bahwa aditif memepengaruhi nilai VIM dan flow. Batas penggunaan maksimal aditif sebesar 0,9\% yang memenuhi Spesifikasi Umum Bina Marga 2018.
\end{abstract}

\section{PENDAHULUAN}

Seiring dengan meningkatnya kepadatan lalu lintas yang melintasi jalan tersebut, maka umur perkerasan akan berkurang dan akan mengurangi kenyaman pengguna jalan. Selain dari faktor tersebut, cuaca juga menjadi penyebab aspal menjadi mudah lapuk dan rusak seperti cuaca kita di Indonesia ini yaitu panas yang menyebabkan adanya oksidasi oleh sinar matahari dan hujan yang menyebabkan aspal menjadi lembab. Hal ini yang mengakibatkan perkerasan jalan akan lebih cepat mengalami kerusakan-kerusakan dini (sebelum masa pelayanan habis), terutama kerusakan yang disebabkan oleh air. Sementara masa pelayanan sangat ditentukan oleh kualitas suatu campuran aspal, dimana kualitas campuran beraspal tersebut tergantung pada beberapa faktor, yaitu antara lain kualitas masing-masing bahan yaitu sifat-sifat fisik agregat, Gradasi agregat, dan sifat fisik aspal itu sendiri.
Salah satu cara untuk mengatasi kerusakankerusakan pada jalan yang diakibatkan oleh air dan kelembaban adalah dengan memperbaiki perilaku campuran beraspalnya, yaitu dengan cara meningkatkan kualitas sifat-sifat aspal, kualitas agregat, dan memperbaiki mekanisme pengolahan dan gradasi agregatnya. Meningkatkan kualitas dari sifat aspal adalah dengan cara memodifikasi aspalnya, atau dengan menambahkan suatu bahan maupun campuran beraspalnya.

Anti Stripping Agent merupakan suatu aditif yang dapat merubah sifat aspal dan agregat, meningkatkan daya lekat dan ikatan sehingga dapat memperpanjang umur rencana suatu perkerasan, serta mengurangi efek negatif dari air dan kelembaban sehingga menghasilkan permukaan berdaya lekat tinggi, ini akan mengurangi terjadinya pelepasan butiran pada aspal. Berdasarkan Spesifikasi Umum Binamarga tahun 2010 Divisi 6 Revisi 3, kuantitas pemakaian 
anti stripping adalah dalam rentang 0,2-0,4\% terhadap berat aspal.

Penggunaan Anti Stripping berupa Amido Polyamine menunjukkan bahwa penambahan sebanyak $0,3 \%$ dari berat aspal AC-WC didapatkan nilai stabilitas, flow, angka pori dan nilai marshall quotient paling mendekati nilai campuran standar serta dapat meningkatkan durabilitas (Aminsyah, 2014). Sedangkan Yogha (2014) melakukan penelitian penggunaan zat aditif anti stripping fatty amido-polyamine sebanyak $0,3 \%$ dari berat aspal sebagai bahan pengikat pada campuran Lapis Tipis Aspal Beton (Lataston) bergradasi senjang perkerasan lentur dengan gradasi agregat berdasarkan batas tengah mempunyai nilai Parameter Marshall yang lebih baik dari Parameter Marshall campuran pembanding dibandingkan dengan variasi lainnya.

Hasil pengujian aspal dengan zat aditif anti stripping wetfix be mempengaruhi kepekaan temperature yang lebih tinggi. Campuran aspal porus dengan penambahan kadar wetfix be $0,3 \%$ merupakan yang paling optimum dalam meningkatkan kinerja struktural dan fungsional campuran aspal porus. Nilai stabilitas meningkat $16,12 \%$ dan nilai ITS meningkat $11.81 \%$. Kinerja campuran aspal porus dalam mempertahankan struktur dari terjadinya bleeding, dan disintegrasi semakin membaik sejalan dengan penambahan kadar anti stripping wetfix be dilihat dari penurunan nilai Cantabro Loss dan AFD. Sedangkan kinerja fungsional campuran aspal porus juga membaik dan koefisien permeabilitas semakin meningkat, yang disebabkan oleh nilai VITM campuran yang semakin besar. Namun, dalam pengujian IRS, perubahannya tidak terlalu signifikan (Yogha, 2014).

Penelitian ini bertujuan untuk mengetahui pengaruh yang terjadi jika penambahan bahan aditif melebihi rentang yang ada Apada Campuran Beton Aspal (AC-WC) dengan menggunakan bahan aditif anti stripping dan tanpa menggunakan bahan tambahan lain. Pada penelitian ini akan dicoba persentase zat aditif lebih besar dari pada kadar kuantitas dari Binamarga yaitu $0 \%, 0,3 \%, 0,5 \%, 0,7 \%, 0,9 \%$, dan $2 \%$ dari berat aspal untuk mengatahui pengaruh yang terjadi pada aspal.
Secara umum dalam penelitian ini untuk mengetahui Kadar Aspal Optimum pada campuran AC-WC, mengetahui kadar anti stripping optimum pada campuran aspal AC-WC dengan KAO yang didapat, dan membandingkan nilai karakteristik Marshall antara KAO tanpa campuran aditif dan KAO dengan campuran aditif.

\section{TINJAUAN PUSTAKA}

\subsection{Aspal}

Fungsi aspal dalam campuran adalah sebagai pengikat yang bersifat visco-elastic dengan tingkat viscositas yang tinggi selama masa layan. Fungsi yang lain adalah sebagai pelumas pada saat penghamparan campuran di lapangan sehingga akan memudahkan pemadatan. AASHTO (1982) menyatakan bahwa jenis aspal keras ditandai dengan angka penetrasinya. Persyaratan toleransi spesifikasi kadar aspal berdasarkan Bina Marga 2018 revisi 2.

\subsection{Agregat}

Agregat merupakan butir-butir batu pecah, kerikil, pasir, atau material lain, baik yang berasal dari alam maupun buatan yang berbentuk mineral padat, agregat juga merupakan komponen utama dari lapisan perkerasan jalan yaitu $90-95 \%$ agregat berdasarkan persentase berat atau $75-85 \%$ agregat berdasarkan persentase volume (Sukirman, 2003). Secara umum agregat yang digunakan dalam campuran beraspal, yaitu:

1. Agregat Kasar

Agregat kasar yaitu batuan yang tertahan disaringan 2,36 $\mathrm{mm}$ atau sama dengan saringan no.8. Agregat kasar sangat penting dalam membentuk kinerja, karena stabilitas dari campuran diperoleh dari interlocking antar agregat. Keuntungan agregat kasar menyebabkan rongga udara meningkat sehingga air mudah masuk dan daya lekatnya menurun (Sukirman, 2003).

2. Agregat Halus

Agregat halus yaitu batuan yang lolos saringan No.8 (2,36mm) dan tertahan saringan No.200 (0,075mm). fungsi utama 
dari agregat halus adalah memberikan stabilitas dan mengurangi deformasi permanen dari campuran melalui interlocking dan gesekan antar partikel.

3. Bahan Pengisi (Filler)

Bahan pengisi (filler) yaitu material yang lolos saringan no.200 $(0,075 \mathrm{~mm})$. Filler berfungsi untuk mengurangi jumlah rongga dalam campuran, jika kadar filler terlampau tinggi cenderung menyebabkan campuran akan mudah retak, pada sisi lain kadar filler yang rendah akan menyebabkan campuran lembek pada temperatur relatif tinggi (Sukirman, 2003).

\subsection{Pengelupasan Perkerasan Aspal}

Stripping merupakan perpindahan film aspal dari permukaan agregat oleh air yang disebabkan oleh kondisi permukaan agregat lebih mudah menyerap air dari pada aspal. Penyebab terjadinya pengelupasan antara lain karena adanya kelembaban berlebih pada Hot Mix Asphalt (HMA).

\subsection{Bahan Anti Pengelupasan}

Bahan anti pengelupasan (Anti Stripping Agent) merupakan suatu bahan tambah yang dapat merubah sifat aspal dan agregat, meningkatkan daya lekat dan ikatan, serta mengurangi efek stripping, performa dari penggunaan Anti Stripping Agent tidak hanya dalam penanganan jangka pendek tetapi untuk jangka panjang juga dalam kurun waktu (34tahun). Pada umumnya, Anti Stripping Agent ditambahkan dalam bentuk cair pada aspal dengan tingkat kadar $(0,25-1,00 \%)$ terhadap berat aspal. Keragaman dari Anti Stripping Agent akan menunjukkan hasil yang berbeda dengan jenis aspal dan kombinasi agregat yang berbeda (Harnish, 2010). Adapun jenis-jenis Anti Stripping Agent adalah:

\section{Anti Stripping Agent Kapur}

Penambahan zat aditif kapur merupakan metode yang dapat meminimalkan kerentanan campuran aspal terhadap kelembaban. Metode yang umum dilakukan yaitu dengan menambahkan $1-1,5 \%$ aditif kapur dari total berat kering agregat dalam campuran. Tiga bentuk aditif kapur yang digunakan, yaitu hydrate lime $\mathrm{Ca}(\mathrm{OH})^{2}$, quick lime $(\mathrm{CaO})$, dan dolomitic lime (tipe $\mathrm{S}$ dan N).

2. Anti Stripping Agent Cair

Anti stripping agent cair adalah senyawa kimia yang mengandung amine. Aspal cair umumnya dicampur bersama anti stripping agent cair sebelum penambahan agregat ke dalam campuran (Hunter, 2001). Beberapa jenis Anti Stripping Agent cair antara lain :

1) Derbo-101

Derbo adlah jenis anti stripping yang berasal dari India. Di negar ini, anti pengelupasan ini telah lama diimpor. Untuk campuran Hotmix, penggunaan Anti Stripping Agent jenis Derbo-401 ini berkisar $0,1 \%-0,4 \%$ dari berat bitumen. Sementara untuk perbaikan jalan, penggunaannya berkisar $0,2 \%$ $0,5 \%$ dari berat bitumen.

2) Morlife 2200

Morlife 2200 adalah jenis anti pengelupasan dengan performa tinggi berdasarkan ilmu-ilmu kimia yang baru dan inovatif. Campuran aspal yang menggunakan Morlife 2200 ini akan memperlihatkan peningkatan daya tahan dan uap sehubungan dengan kerusakan dan pengelupasan.

3) Wetfix-BE

Wetfix merupakan salah satu dari jenis anti stripping yang memiliki kesensitifan yang cukup tinggi, selain harganya yang relative mahal dan penambahan jumlahnya terhadap campuran aspal sangat sedikit, akan tetapi menghasilkan stabilitas yang cukup baiK.

4) T-MEN L300A

T-MEN L300A adalah agen antipengelupasan berbasis amina yang mengubah tegangan antarmuka antara aspal dan agregat, memperkuat ikatan untuk daya tahan jangka panjang. TMEN L300A dirancang untuk mengatasi masalah tersebut dengan 
meningkatkan daya rekat aspal dan memastikan stabilitas perkerasa aspal. Berbentuk berupa cairan kuning bening. Dosis penggunaan $0,2 \%-0,4 \%$.

\subsection{Pengujian Stabilitas Marshall (Marshall Test)}

Pengujian Marshall adalah suatu metode pengujian untuk mengukur ketahanan stabilitas terhadap kelelehan flow dari campuran aspal dengan menggunakan alat Marshall. Kriteria pengujian Marshall, yaitu:

1. Stabilitas

Stabilitas lapisan pekerjaan jalan ialah kemampuan lapisan perkerasan menerima beban lalu lintas tanpa terjadi perubahan bentuk tetap seperti gelombang, alur ataupun bleeding. Stabilitas dapat dihitung dengan rumus:

$$
\mathrm{S}=\mathrm{p} \times \mathrm{q} \times \mathrm{r}
$$

\section{Kelelehan (flow)}

Kelelehan adalah perubahan bentuk benda uji campuran aspal beton saat akan runtuh yang didapat dari pembacaan dial flow pada alat Marshall sat pengujian.

3. Berat Volume (density)

Berat volume merupakan perbandingan antara berat benda uji dengan volumenya. Nilai berat volume dihitung dengan rumus:

$$
\mathrm{Q}=\frac{c}{f}
$$

4. Volume Pori dalam Agregat Campuran (VMA)

Volume pori dalam agregat campuran (Void in mineral aggregate) adalah banyaknya pori diantara butir-butir agregat didalam aspal beton padat, dinyatakan dengan persentase (Sukirman, 2003), dihitung dengan rumus:

$$
\begin{aligned}
\mathrm{VMA}= & \left(100-\frac{G m b \times P s}{G s b}\right) \% \text { dari volume bulk } \\
& \text { beton aspal padat }
\end{aligned}
$$

5. Volume Pori dalam beton aspal padat (VIM) VIM adalah banyaknya pori diantara butir agregat yang diselimuti aspal. VIM dinyatakan dalam persentase terhadap volume beton aspal padat (Sukirman, 2003).
Dasar perhitungan yang dilakukan berdasarkan volume beton aspal padat $=100$ $\mathrm{cm}^{3}$ dihitung dengan rumus:

VIM $=\left(100-\frac{G m m \times G m b}{G m m}\right) \%$ dari volume bulk beton aspal padat (4)

6. Volume Pori Antara Butir Agregat Terisi Aspal (VFB)

VFB adalah bagian dari VMA yang terisi oleh aspal, tidak termasuk didalamnya aspal yang terabsorpsi oleh masing-masing butir agregat. VFB inilah yang merupakan persentase volume beton aspal padat yang menjadi film atau selimut aspal. Dasar perhitungan dilakukan berdasarkan volume beton aspal padat $=100 \mathrm{~cm}^{3}$, dihitung dengan rumus:

$$
\mathrm{VFB}=\frac{100(V M A-V I M)}{V M A} \% \text { dari VMA (5) }
$$

7. Marshall Quotient (MQ)

Tinggi nilai MQ menunjukkan sifat campuran akan semakin kaku dan semakin rentan terhadap keretakan.

Wetfix-BE dengan kadar $0,5 \%$ memiliki nilai Marshall Sisa 96,41\% lebih tinggi dibandingkan dengan penggunaan anti striping Derbo-401 dan Morlife 2200. (Sembiring, 2012). Didapat bahwa penambahan Anti Stripping Agent jenis Derbo-401 memiliki keunggulan dibandingkan Anti Stripping Agent jenis WetfixBE. (Panjaitan, 2012). Didapat nilai optimum penggunaan ASA untuk jenis Wetbond-SP dan Wetfix-BE terhadap dua sumber agregat yang berbeda berkisar antara $0,2-0,4 \%$ dan telah memenuhi standar Spesifikasi Umum Binamarga 2010 Revisi 3. (Dian, 2018).

\section{METODOLOGI}

Persiapan alat dan bahan. Adapun bahan terdiri dari aspal, zat aditif anti stripping, agregat kasar, agregat halus, dan filler. Pengujian yang dilakukan pada aspal yaitu penetrasi, titik lembek, titik nyala, berat jenis dan daktilitas. Pada agregat kasar dilakukan pengujian berupa analisa saringan, berat jenis, penyerapan air dan keausan agregat kasar. Pengujian yang dilakukan pada agregat halus yaitu analisa saringan, berat jenis, dan penyerapan air. Pada filler dilakukan pengujian berupa analisa saringan, berat jenis, dan 
penyerapan air. Jika semua pengujian memenuhi spesifikasi maka dilanjutkan dengan penentuan kadar aspal optimum (KAO). Dilanjutkan pembuatan benda uji dengan KAO dan variasi kadar aditif sebesar 0\%, 0,3\%, 0,5\%, 0,7\%, 0,9\% dan $2 \%$. Selanjutnya dilakukan pengumpulan data dan analisis perhitungan kemudian kesimpulan dari penelitian.

\section{HASIL DAN PEMBAHASAN}

\subsection{Pengujian Aspal}

1. Pengujian Penetrasi Aspal

Pengujian Penetrasi aspal ini untuk menentukan penetrasi aspal keras atau lembek (Solit atau Semi Solit), di Laboratorium didapat hasil bacaan pada alat penetrasi yaitu 63, 65, 64, 67, 66 sehingga nilai penetrasi rata-rata aspal yang diuji adalah 65 .

2. Pengujian Daktilitas Aspal

Pengujian daktilitas pada pengujian ini Panjang benda uji yaitu $103 \mathrm{~cm}$, yang mana pengujian ini daktilitas aspal yang diuji sudah memenuhi syarat yaitu minimal $100 \mathrm{~cm}$ (Spesifikasi Umum 2018 divisi 6 Perkerasan Aspal).

3. Pengujian Berat Jenis Aspal

Pengujian Berat Jenis Aspal di Laboratorium didapatkan besar Berat Jenis Aspal adalah 1,046 gram, yang mana hasil dari pengujian ini memenuhi yaitu (Spesifikasi Umum 2018 divisi 6 Perkerasan Aspal)

4. Pengujian Titik Lembek Aspal

Pengujian Titik Lembek Aspal didapatkan nilai suhu aspal mencapat titik lembeknya yaitu pada benda uji 1 sebesar $63^{\circ} \mathrm{C}$ dan benda uji $264^{\circ} \mathrm{C}$ dengan selisih $1^{\circ} \mathrm{C}$ dan rata-rata yaitu $63,5^{\circ} \mathrm{C}$. Nilai ini sudah memenuhi spesifikasi nilai titik lembek untuk aspal penetrasi $60 / 70$ yaitu $\geq 48^{\circ} \mathrm{C}$.

5. Pengujian Titik Nyala dan Titik Bakar Aspal Pengujian ini didapatkan suhu titik nyala adalah $305^{\circ} \mathrm{C}$ dan suhu titik bakar adalah $308^{\circ}$ C. Hasil ini sudah sesuai dengan spesifikasi untuk aspal 60/70 yaitu titik nyala minimal $232^{\circ} \mathrm{C}$.

\subsection{Pengujian Agregat Kasar}

1. Pengujian Analisis Saringan

Pengujian ini untuk pemeriksaan dan menentukan pembagian butir (gradasi) agregat kasar dengan menggunakan satu set saringan seperti pada Tabel 1 .

Tabel 1. Analisa Saringan Agregat Kasar

\begin{tabular}{ccccc}
\hline Sieve & Retained & Cummulative & \multicolumn{2}{c}{ Percent } \\
\cline { 2 - 5 } No. & Weight (gr) & Retained (gr) & Retained & Pass \\
\hline$\# 1$ & 0 & 0 & 0 & 100 \\
\hline$\# 3 / 4$ & 0 & 0 & 0 & 100 \\
\hline$\# 1 / 2$ & 244 & 244 & 12,20 & 87,80 \\
\hline$\# 3 / 8$ & 381,2 & 625 & 31,26 & 68,74 \\
\hline$\# 4$ & 463,5 & 1089 & 54,44 & 45,57 \\
\hline$\# 8$ & 536,3 & 1625 & 81,25 & 18,75 \\
\hline$\# 16$ & 223,7 & 1849 & 92,44 & 7,57 \\
\hline$\# 30$ & 107 & 1956 & 97,79 & 2,22 \\
\hline$\# 50$ & 35 & 1991 & 99,54 & 0,47 \\
\hline$\# 100$ & 8,4 & 1999 & 99,96 & 0,05 \\
\hline$\# 200$ & 0,9 & 2000 & 100,00 & 0,00 \\
\hline PAN & 0 & 2000 & 100,00 & 0,00 \\
\hline & & & &
\end{tabular}

2. Pengujian Berat Jenis dan Penyerapan Air Agregat Kasar

Pengujian ini didapatkan berat jenis (Bulk) sebesar 2,56 gr, berat jenis kering permukaan jenuh (SSD) sebesar 2,63 gr, berat jenis semu adalah $2,70 \mathrm{gr}$ dan penyerapan airnya sebesar $0,015(<3 \%)$.

3. Pengujian Keausan Agregat dengan mesin Abrasi Los Angeles

Pada pengujian ini berat benda uji sebesar 5000 gr menggunakan grading $\mathrm{B}$, dalam pengujiannya benda uji no 1 yaitu berat benda uji tertahan saringan No.1/2 adalah 2500 gr, berat lolos saringan No.1/2 adalah 2500 gr, persentase keausan adalah $32 \%$.

\subsection{Pengujian Agregat Halus}

1. Pengujian Analisis Saringan Pengujian ini untuk pemeriksaan dan menentukan pembagian butur (gradasi) agregat halus yaitu pasir Cempaka dengan menggunakan satu set saringan seperti pada Tabel 2. 
Tabel 2. Analisa Saringan Agregat Halus

\begin{tabular}{ccccc}
\hline Sieve & Retained & Cummulative & \multicolumn{2}{c}{ Percent } \\
\cline { 2 - 5 } No. & Weight (gr) & Retained (gr) & Retained & Pass \\
\hline$\# 1$ & 0 & 0 & 0 & 100 \\
\hline$\# 3 / 4$ & 0 & 0 & 0 & 100 \\
\hline$\# 1 / 2$ & 0 & 0 & 0 & 100 \\
\hline$\# 3 / 8$ & 0 & 0 & 0 & 100 \\
\hline$\# 4$ & 0 & 0 & 0 & 100 \\
\hline$\# 8$ & 67 & 67 & 6,70 & 93,30 \\
\hline$\# 16$ & 254 & 321 & 32,10 & 67,90 \\
\hline$\# 30$ & 374,6 & 695,6 & 69,56 & 30,44 \\
\hline$\# 50$ & 98 & 793,6 & 79,36 & 20,64 \\
\hline$\# 100$ & 122,4 & 916 & 91,60 & 8,40 \\
\hline$\# 200$ & 84 & 1000 & 100,00 & 0 \\
\hline PAN & 0 & 1000 & 100,00 & 0 \\
\hline
\end{tabular}

2. Pengujian Berat Jenis dan Penyerapan Air Agregat Halus

Pada pengujian ini didapat berat jenis agregat halus pasir Cempaka didapatkan berat jenis (Bulk) sebesar 1,82 gr, berat jenis kering permukaan jenuh (SSD) sebesar 2,07 gr, berat jenis semu adalah 2,30 gr dan penyerapan airnya sebesar $0,116 \quad(<3 \%)$. Agregat halus sudah memenuhi ketentuan mutu pasal 6.3.2(1) yaitu penyerapan air oleh agregat maksimum $3 \%$.

\subsection{Pengujian Filler}

1. Pengujian Analisis Saringan

Pengujian ini untuk pemeriksaan dan menentukan butir (gradasi) Filler yaitu dari Abu Batu dengan menggunakan satu set saringan seperti pada Tabel 3.
Tabel 3. Analisa Saringan Filler

\begin{tabular}{ccccc}
\hline \multirow{2}{*}{$\begin{array}{c}\text { Sieve } \\
\text { No. }\end{array}$} & $\begin{array}{c}\text { Retained } \\
\text { (gr) }\end{array}$ & Cummulative & \multicolumn{2}{c}{ Percent } \\
\hline$\# 1$ & 0 & 0 & 0 & Pass \\
\hline$\# 3 / 4$ & 0 & 0 & 0 & 100 \\
\hline$\# 1 / 2$ & 0 & 0 & 0 & 100 \\
\hline$\# 3 / 8$ & 0 & 0 & 0 & 100 \\
\hline$\# 4$ & 0 & 0 & 0 & 100 \\
\hline$\# 8$ & 0 & 0 & 0 & 100 \\
\hline$\# 16$ & 0 & 0 & 0 & 100 \\
\hline$\# 30$ & 0 & 0 & 0 & 100 \\
\hline$\# 50$ & 0 & 0 & 0 & 100 \\
\hline$\# 100$ & 0 & 0 & 0 & 100 \\
\hline$\# 200$ & 235 & 235 & 30,7189 & 69,28105 \\
\hline PAN & 765 & 765 & 100 & 0 \\
\hline
\end{tabular}

2. Penguian Berat jenis dan Penyerapan Air Filler

Pada pengujian ini didapatkan berat jenis (Bulk) sebesar 2,04 gr, berat jenis kering permukaan jenuh (SSD) sebesar 2,24 gr, berat jenis semu adalah 2,66 gr dan penyerapan airnya sebesar $0,114 \quad(<3 \%)$. Agregat halus sudah memenuhi ketentuan mutu pasal 6.3.2(1) yaitu penyerapan air oleh agregat maksimum $3 \%$.

\subsection{Data Gradasi Agregat Gabungan}

Campuran aspal yang direncanakan adalah campuran aspal AC- Wearing Course (WC), dari hasil pemeriksaan agregat akan disusun suatu gradasi agregat gabungan yang memenuhi spesifikasi gradasi agregat untuk aspal ACWearing Course (WC). Presentase masingmasing agregat dapat dilihat pada Tabel 4.

Tabel 4. Gradasi Agregat Gabungan

\begin{tabular}{|c|c|c|c|c|c|c|c|c|}
\hline No. & \multicolumn{2}{|c|}{ Agregat Kasar } & \multicolumn{2}{|c|}{ Agregat Halus } & \multicolumn{2}{|c|}{ Filler } & Jumlah & Spec. \\
\hline Saringan & \multicolumn{2}{|c|}{$65 \%$} & \multicolumn{2}{|c|}{$29 \%$} & \multicolumn{2}{|r|}{$6 \%$} & Total & Gradasi \\
\hline & Lolos & & Lolos & & Lolos & & & \\
\hline$\# 3 / 4$ & 100 & 65 & 100 & 29 & 100 & 6 & 100,00 & 100 \\
\hline$\# 1 / 2$ & 87,80 & 57,07 & 100 & 29 & 100 & 6 & 92,07 & $90-100$ \\
\hline$\# 3 / 8$ & 68,74 & 44,68 & 100 & 29 & 100 & 6 & 79,68 & $77-90$ \\
\hline$\# 4$ & 46 & 29,62 & 100 & 29 & 100 & 6 & 64,62 & $53-69$ \\
\hline$\# 8$ & 18,75 & 12,19 & 93 & 27,06 & 100 & 6 & 45,24 & $33-53$ \\
\hline$\# 16$ & 7,57 & 4,92 & 68 & 19,69 & 100 & 6 & 30,61 & $21-40$ \\
\hline$\# 30$ & 2,22 & 1,44 & 30,44 & 8,83 & 100 & 6 & 16,27 & $14-30$ \\
\hline$\# 50$ & 0,47 & 0,30 & 20,64 & 5,99 & 100 & 6 & 12,29 & $9-22$ \\
\hline$\# 100$ & 0,0 & 0,03 & 8,4 & 2,44 & 100 & 6 & 8,47 & $6-15$ \\
\hline$\# 200$ & 0,00 & 0 & 0,00 & 0 & 69,28 & 4,156863 & 4,16 & $4-9$ \\
\hline
\end{tabular}




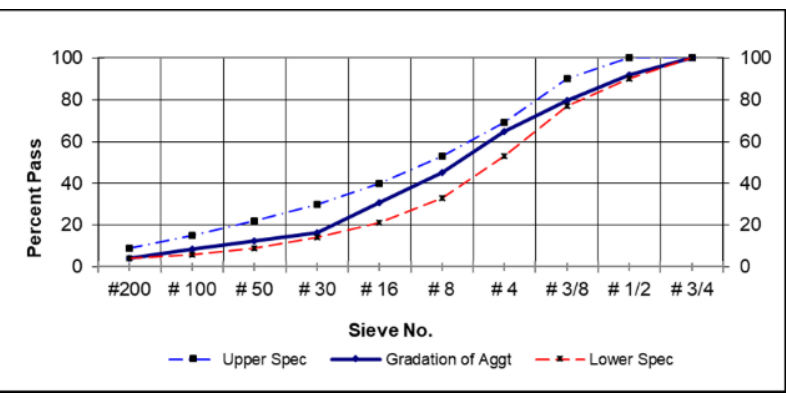

Gambar 1. Grafik Gradasi Gabungan Aspal ACWC

\subsection{Kadar Aspal Rencana (Pb)}

Setelah gradasi gabungan agregat didapatkan maka bisa ditentukan kadar aspal rencana $(\mathrm{Pb})$ dengan rumus:

$$
\begin{aligned}
& \mathrm{Pb}=0,035(\% \mathrm{CA})+0,045(\% \mathrm{FA})+0,18 \\
& (\% \text { Filler })+\mathrm{K} \quad \mathrm{K}=1 \\
& \mathrm{~Pb}=0,035(54,842)+0,045(41)+0,18 \\
& \begin{aligned}
(4,157)+2 \\
\quad=6,512
\end{aligned}
\end{aligned}
$$

\subsection{Pengujian Marshall Mendapatkan Nilai \\ KAO}

Dari hasil pengujian marshall untuk mendapatkan nilai KAO tanpa campuran zat aditif Anti Stripping Agent, setiap benda uji

\begin{tabular}{|c|c|c|c|c|}
\hline \multirow[t]{2}{*}{ Paramater Marshall } & \multicolumn{3}{|c|}{ Kadar Aspal } & \multirow[t]{2}{*}{$\begin{array}{l}\text { Spefisi } \\
\text { fikasi }\end{array}$} \\
\hline & $5 \%$ & $3-5 \%$ & $7 \%$ & \\
\hline Kepadatan (t/m3) & 2,14 & $>15 \%$ & 2,13 & - \\
\hline VIM (\%) & 5,47 & $>65 \%$ & 3,72 & $3-5 \%$ \\
\hline VMA (\%) & 16,10 & $>800 \%$ & 18,64 & $>15 \%$ \\
\hline VFB $(\%)$ & 67,96 & $2-4 \mathrm{~mm}$ & 83,41 & $>65 \%$ \\
\hline Stabilitas (kg) & 1160,78 & $>80 \mathrm{~kg} / \mathrm{mm}$ & 1117,83 & $\begin{array}{c}>800 \\
\% \\
\end{array}$ \\
\hline Kelelehan (mm) & 3,65 & - & 3,26 & $\begin{array}{c}2-4 \\
\mathrm{~mm}\end{array}$ \\
\hline $\begin{array}{c}\text { Hasil Bagi Marshall } \\
(\mathrm{kg} / \mathrm{mm})\end{array}$ & 318,68 & $3-5 \%$ & 343,82 & $\begin{array}{c}>80 \\
\mathrm{~kg} / \mathrm{mm}\end{array}$ \\
\hline
\end{tabular}
dipadatkan sebanyak 75 kali tumbukan. Data yang didapatkan dapat dilihat pada Tabel 5.

Tabel 5. Nilai Pengujian KAO Rencana Tanpa

$$
\text { Zat Aditif }
$$

Dapat diketahui kadar aspal optimum sebesar $6,125 \%$ karena pada titik-titik ini semua parameter Marshall yang dihasilkan memenuhi semua Spesifikasi Umum Bina Marga Tahun 2018 seperti terlihat pada Gambar 2.

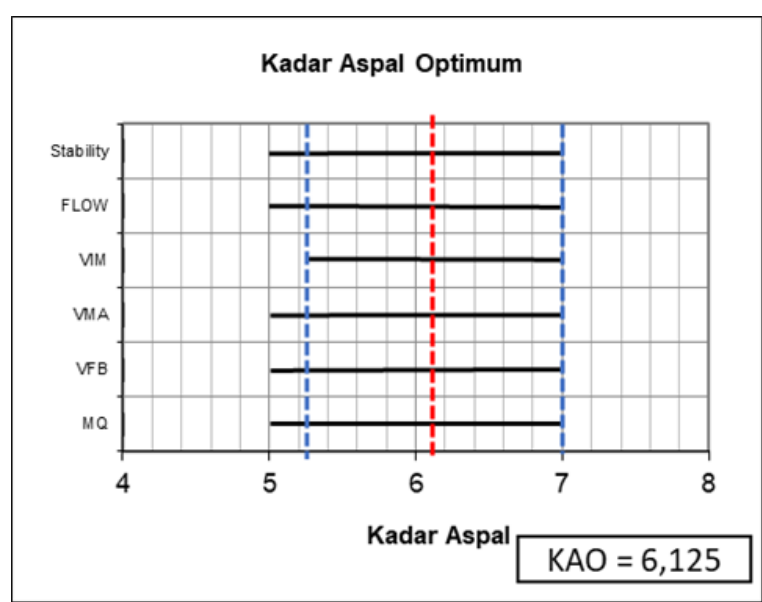

Gambar 2. Kadar Aspal Optimum Aspal ACWC

Hasil dari garfik hubungan antara kadar aspal optimum dan campuran aspal AC-Wearing Course sesuai Spesifikasi Umum Bina Marga Tahun 2018 bisa dilihat pada Tabel 6 .

Tabel 6. Hasil Karakteristik Kadar Aspal Optimum Campuran Aspal AC-WC

\begin{tabular}{cccc}
\hline $\begin{array}{c}\text { Karakteristik } \\
\text { Campuran }\end{array}$ & Spesifikasi & $\begin{array}{c}\text { KAO } \\
(6,125 \%)\end{array}$ & Ket. \\
\hline VIM & $3 \%-5 \%$ & 3,8 & Memenuhi \\
\hline VMA & Min. 15\% & 16,9 & Memenuhi \\
\hline VFB & Min. 65\% & 81 & Memenuhi \\
\hline Stabilitas & $\begin{array}{c}\text { Min. } 800 \\
\text { Kg }\end{array}$ & 1550 & Memenuhi \\
\hline \multicolumn{5}{c}{ Flow } & $2 \mathrm{~mm}-4 \mathrm{~mm}$ & 3,5 & Memenuhi \\
\hline MQ & $\mathrm{Min} .80$ & & \\
& $\mathrm{Kg} / \mathrm{mm}$ & 445 & Memenuhi \\
\hline
\end{tabular}

\subsection{Hasil Pengujian Benda Uji Marshall ( Sesudah KAO)}

Hasil perhitungan seluruh parameter Marshall pada uji Marshall (sesudah KAO) dengan penambahan variasi Anti Stripping Agent (ASA) disajikan dalam bentuk tabel dan grafik. 
Tabel 7. Pengujian Marshall dengan Anti Stripping Agent

\begin{tabular}{|c|c|c|c|c|c|c|c|}
\hline \multirow{2}{*}{$\begin{array}{c}\text { Parameter } \\
\text { Marshall }\end{array}$} & \multicolumn{6}{|c|}{ Kadar Anti Stripping Agent (\%) } & \multirow{2}{*}{ Spesifikasi } \\
\hline & 0 & 0,3 & 0,5 & 0,7 & 0,9 & 2 & \\
\hline Kepadatan (t/m3) & 2,16498 & 2,155119 & 2,161147 & 2,162701 & 2,168896 & 2,192942 & - \\
\hline VIM $(\%)$ & 3,228485 & 3,669235 & 3,39978 & 3,330357 & 3,053437 & 2,131172 & $3-5 \%$ \\
\hline VMA $(\%)$ & 16,44127 & 16,82184 & 16,58918 & 16,52924 & 16,29012 & 15,23379 & $>15 \%$ \\
\hline VFB $(\%)$ & 83,29706 & 81,04837 & 82,40864 & 82,77435 & 84,22137 & 89,13257 & $>65 \%$ \\
\hline Stabilitas (kg) & 1567,023 & 1399,093 & 1450,543 & 1396,099 & 1322,929 & 904,236 & $>800 \mathrm{~kg}$ \\
\hline Kelelehan (mm) & 3,94 & 3,705 & 3,85 & 3,755 & 3,5 & 1,86 & $2-4 \mathrm{~mm}$ \\
\hline $\begin{array}{c}\text { Hasil Bagi } \\
\text { Marshall }(\mathrm{kg} / \mathrm{mm})\end{array}$ & 398,2625 & 377,3847 & 376,2705 & 372,3475 & 378,093 & 487,3036 & $>80 \mathrm{~kg} / \mathrm{mm}$ \\
\hline
\end{tabular}

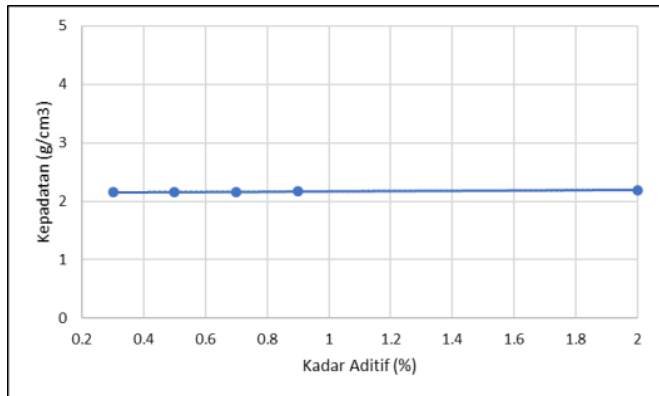

Gambar 3. Grafik Hubungan Antara Aspal dengan Kepadatan



Gambar 4. Grafik Hubungan Antara Aspal dengan Stabilitas AC-WC



Gambar 5. Grafik Hubungan Antara Aspal dengan Flow



Gambar 6. Grafik Hubungan Antara Aspal dengan Rongga Terisi Aspal (VFB)

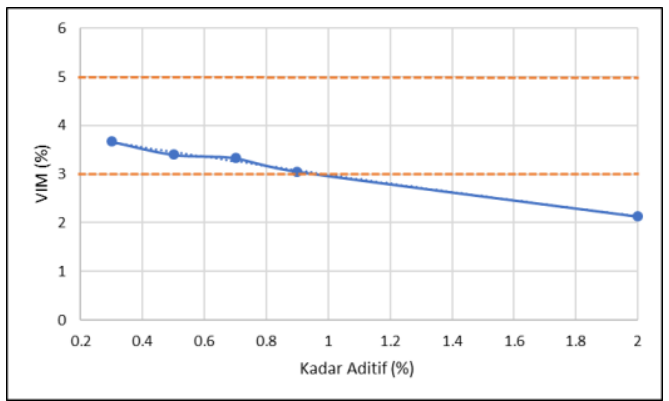

Gambar 7. Grafik Hubungan Antara Aspal dengan Rongga Udara Dalam Campuran (VIM)

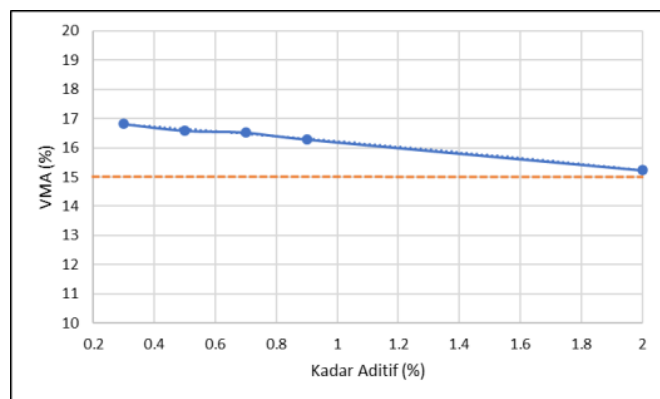

Gambar 8. Grafik Hubungan Antara Aspal dengan Rongga Udara Diantara Minerat Agregat (VMA) 




Gambar 9. Grafik Hubungan Antara Aspal dengan MQ

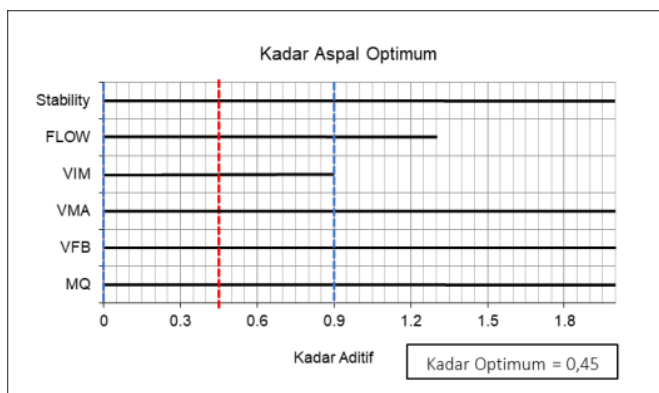

Gambar 10. Kadar Optimum Zat Aditif Anti Stripping

\section{UCAPAN TERIMA KASIH}

Terima kasih diucapkan kepada semua pihak yang telah membantu dalam kelancaran proses penelitian ini.

\section{KESIMPULAN}

Dari hasil penelitian pada campuran aspal AC-WC dengan campuran zat aditif anti stripping dengan kadar $0 \%, 0,3 \%, 0,6 \%, 0,7 \%, 0,9 \%$, dan $2 \%$ dengan menggukan Spesifikasi Umum Bina Marga 2018, diperoleh nilai optimum kadar aspal AC-WC yang didapat dari pengujian marshall adalah sebesar $6,125 \%$.

Penggunaan Anti Stripping Agent T-MEN L300A didapat nilai optimum sebesar $0,45 \%$. Dari segi efisiensi penggunaan kadar 0,3\% - 0,5\% sudah cukup memenuhi standar spesifikasi Binamarga 2018.

Hasil penelitian didapatkan Perbandingan hasil uji marshall antara campuran tanpa menggunakan aditif dan campuran dengan aditif yaitu, nilai kepadatan, stabilitas, flow, VFB, dan
MQ campuran tanpa aditif lebih besar dibandingkan dengan campuran menggunakan aditif. Sedangkan nilai VMA dan VIM campuran tanpa aditif lebih kecil dibandingkan dengan campuran menggunakan aditif.

Penelitian lanjutan perlu dilakukan untuk mendapatkan informasi lebih banyak seperti pengujian stabilitas marshall sisa dan rongga dalam campuran pada kepadatan membal (refusal) sesuai dengan spesifikasi Bina Marga 2018.

\section{DAFTAR PUSTAKA}

AASHTO. (1982). Standart Spesification for Transportation Materials and Metohd of Sampling and Testing, Part II, Specification, $13^{\text {th }}$ Edition, Washington, D.C.

Aminsyah, M. (2014). Studi Eksperimental Penambahan Zat Aditif Anti Stripping Pada Kinerja Campuran Aspal Beton (AC-WC). Jurnal Teknik Sipil dan Lingkungan, 2(4), pp. 642-647.

Cristopher, Y., Pranoto, B. B., Wijaya, D., Zebua, T. A., \& Makmur, A. (2016). Pengaruh Aditif Anti Stripping Agent Terhadap Campuran Aspal. Jurnal Teknik dan Ilmu Komputer, 5(18), pp. 157-165.

Purba, D. P. (2018). Penentuan Kadar Optimum Anti Stripping Agent Wetbond-SP dan Wetfix-BE Terhadap Campuran Aspal Panas AC-WC. Tugas Akhir. Universitas Sumatera Utara.

Direktorat Jendral Bina Marga. (2018). Perkerasan Lentur Jalan Raya. Spesifikasi Umum Divisi 6.

Harnish, C. I. (2010). Liquid Anti-Stripping Technology \& Best Practices. Overland Park, KS: ArrMaz Custom Chemicals.

Hunter, E. R. (2001). Evaluating Moisture Susceptibility of Asphalt Mixes, [Disertasi], Laramie, Wyoming: University of Wyoming.

Panjaitan, B.C., \& Muis Z.A,. (2012). "Studi Pengaruh Penggunaan Variasi Anti Stripping Agent Wetfix-BE dan Derbo-401 Terhadap Karakteristik Campuran Beton Aspal Lapis Pondasi Atas (AC-Base)". Universitas Sumatera Utara. 
Sembiring, H.A., \& Muis Z.A., (2012), "Pengaruh Penggunaan Variasi Anti Stripping Agent Terhadap Karakteristik Beton Aspal Lapis Aus (AC-WC)". Universitas Sumatera Utara.

Sukirman, Silvia. (2003). Beton Aspal Campuran Panas. Jakarta. Yayasan Obor Indonesia.
Yogha, C. (2014). Pengaruh Penambahan Aditif Fatty Amido-Polyamine Pada Campuran Lapis Tipis Aspal Beton (HRS-WC). Diploma thesis, Universitas Andalas. 